\title{
The Development and Validation of an Instrument of Prospective Science Teachers' Perceptions of Scientific Literacy
}

\author{
Hadi Suwono $^{1^{*}(D)}$, Lailil Maulidia ${ }^{1}$ (D), Muhammad Saefi ${ }^{1,2}$ (D), Sentot Kusairi ${ }^{3}$ (D), \\ Chokchai Yuenyong 4 (iD \\ ${ }^{1}$ Department of Biology, Universitas Negeri Malang, INDONESIA \\ 2 Department of Biology, Universitas Islam Negeri Maulana Malik Ibrahim Malang, INDONESIA \\ ${ }^{3}$ Department of Physics, Universitas Negeri Malang, INDONESIA \\ ${ }^{4}$ Science Education Program, Faculty of Education, Khon Kaen University, THAILAND
}

Received 10 November 2021 - Accepted 21 December 2021

\begin{abstract}
Science teachers are the primary agents in developing students' scientific literacy. Therefore, it is essential to identify teachers' perceptions of scientific literacy in order to increase students' scientific literacy. This study was designed to develop and validate an instrument of Indonesian science teachers' perceptions of scientific literacy. The questionnaire was developed based on previous research findings and focus group discussions involving six experts. The factors and internal consistency were examined by involving 808 students from various universities in Indonesia. Validity and reliability were tested using exploratory factor analysis and confirmatory factor analysis. This study results showed 41 questionnaire items with acceptable internal validity and consistency. The questionnaires are recommended as a measure of the development of perceptions of prospective science teachers.
\end{abstract}

Keywords: confirmatory factor analysis, development, exploratory factor analysis, science teacher, scientific literacy, validation

\section{INTRODUCTION}

Scientific literacy is the primary goal of science education in the 21st century. Regarding scientific literacy, international science education communities are concerned about what competencies have to be achieved by 21st-century citizens, including in Indonesia (Faisal \& Martin, 2019). Scientific literacy focuses on citizens' competencies to make decisions about daily societal issues, considering the proliferation of scientific, informational, and technological advances. The identified essential knowledge and competencies, for example, include understanding the nature of science, information management skills, and communicating and collaborating with others (Ke et al., 2021). These identified vital aspects of knowledge and competencies are expected to integrate with science standards, the curriculum, or teaching materials (Mun et al., 2015). Despite this consensus view of scientific literacy, scientific literacy is perceived among science educators as situated in different sociocultural views of learning. Therefore, scientific literacy is a socially constructed concept that changes with context and time (Laugksch, 2000; Yuenyong \& Narjaikaew, 2009).

Some non-Western science educators have developed frameworks of scientifically literate citizens in contemporary society. For example, research from Australia, China, and South Korea has provided key domains of science learning related to societal changes that need to be introduced to students through political, sociocultural, and economic environments. For Australia, Tytler (2007) defined scientific literacy with reference to binding domains of science learning that enabled students to make responsible decisions; be accountable for their actions; and communicate within their local, national, and global communities. For China, Zhang et al. (2005) stated that scientific literacy involved about preparing students for a 21st-century society by enhancing their ability to solve everyday problems. To

(c) 2022 by the authors; licensee Modestum. This article is an open access article distributed under the terms and conditions of the Creative Commons Attribution License (http://creativecommons.org/licenses/by/4.0/). 


\section{Contribution to the literature}

- Identifying teachers' perceptions of scientific literacy is essential for raising students' scientific literacy.

- In Indonesia, there is low awareness of instruments as a key tool for measuring the development of scientific literacy perceptions in prospective science teachers.

- This study presents exploratory factor analysis and confirmatory factor analysis results of a draft instrument assessing student scientific literacy perceptions.

achieve scientific literacy, Chinese science educators have tried to find ways to enhance the successful implementation of science and technology studies, scientific inquiry, and science learning in traditional classrooms (Liang \& Yuan, 2008; Wei \& Thomas, 2005; Zhang et al., 2005). South Korean science educators have adapted sociocultural perspectives on scientific literacy. For example, Mun et al. (2015) developed the Global Scientific Literacy Questionnaire (GSLQ) to examine students' scientific literacy in the 21st century. The GSLQ has been implemented in Australia, China, and South Korea.

Clarifying the elements of the GSLQ may help us make sense of scientific literacy through a sociocultural lens. The GSLQ examines student perceptions that represent their scientific literacy as global citizens in four dimensions: habits of mind, character and values, science as a human endeavor, and meta-cognition and self-direction. Habits of mind refer to competencies 1) to solve complex problems in particular contexts (e.g., personal, societal, and global contexts) by collaborating and communicating with others; 2) to find and use suitable capital; and 3) to develop an argument using evidence and reasoning. Therefore, critical elements of habits of mind consist of communication and collaboration and systematic thinking and information management. Character and values constitute the driving force for individuals to treat global issues sensitively and with respect and to be sympathetic and compassionate toward other human beings and the environment. Key elements of character and values include ecological worldview, social and moral compassion, and socio-scientific accountability. Science as a human endeavor involves global citizens who understand the relationship between science and society. A scientifically literate person understands that science and scientific knowledge are human enterprise products and have a theory-laden, tentative, empirical, collaborative, and interdisciplinary nature. Metacognition and self-direction refer to individuals who can reflect their knowledge. They explicitly find new information to solve problems and evaluate their learning and knowledge processes for lifelong learning (Mun et al., 2015).

Scientific literacy is crucial from the level of elementary education through to universities, especially in developing countries. According to Davies and Priestley (2017) in the Network for Information and
Digital Access report, Indonesia, as a developing country, needs to foster its citizens' scientific literacy to cement scientific knowledge and thinking skills relevant to facing life's problems. In addition, a scientifically literate society is assumed to be a significant prerequisite for developing countries to achieve rapid economic growth (Laugksch, 2000). According to Davies and Priestley (2017), Indonesia has done an excellent job in transforming education and can be used as a valuable source of information for evaluating the development of scientific literacy.

There are similarities in the scientific literacy skills of science teachers across several developing countries. In Indonesia, although teachers have a positive response to scientific literacy (Basam et al., 2017), they have relatively low knowledge and skills in implementing learning (Subiantoro et al., 2015). Research in other developing countries, such as Alebous (2013) for Jordan, has found that science teachers do not have adequate teaching science performance and low scientific literacy skills. According to Sarkar and Corrigan (2014), although science teachers have the correct perspective on scientific literacy, science learning tends to be traditional in Bangladesh. In South Africa, teachers cannot effectively transmit the government-designed curriculum to achieve scientific literacy skills in students (Lelliott, 2014). The problem of developing countries in fostering scientific literacy lies with teachers, who have insufficient ability to apply scientific literacy in the classroom.

Science teachers are a key facilitator in developing students' scientific literacy. Teachers with scientific literacy find it easier to develop students' scientific literacy (Ozdem et al., 2010). A science teacher with high scientific literacy and knowledge also has strong intrinsic motivation to teach science, appreciates the nature of science, and is sensitive to science education quality (Cavas et al., 2013). The process of selfdevelopment influences the quality of science teachers. Al Sultan et al. (2018) suggested that prospective science teachers need to develop more enjoyment in teaching science and improve their scientific literacy skills to succeed in teaching science to students.

The evaluation of the scientific literacy skills of prospective science teachers in Indonesia has yielded disappointing results. Fakhriyah et al. (2017) showed that scientific literacy skills of prospective science teachers are low and not significantly different from 
students' scientific literacy abilities, as reported by the Program for International Student Assessment. Other studies have also found that prospective science teachers' scientific literacy abilities remain low (Pahrudin et al., 2019; Sartika et al., 2018). Sunarti (2015) reported that prospective science teachers generally can solve scientific literacy items only at a low cognitive level.

Various efforts have been made to improve the scientific literacy skills of Indonesian science teacher candidates during their education; one is the application of supportive learning strategies. Teaching methods that are widely applied to improve scientific literacy are student-centered learning (Hwang et al., 2018), such as guided inquiry (Ristanto et al., 2017), problem-based learning (Ardianto \& Rubini, 2016; Ratini et al., 2018; Suwono et al., 2019), project-based learning (SantamaríaCárdaba, 2020), science, technology, and society (Ratini et al., 2018), and discovery (Ardianto \& Rubini, 2016). However, the scientific literacy capabilities achieved by applied learning are still unsatisfactory. Al-Momani (2016) found that no specific variables influenced students' scientific literacy skills.

Holbrook and Rannikmae (2009) explained that the development of scientific literacy skills alone cannot yield successful classroom learning strategies. Educators need to pay attention to the initial perceptions of students about learning. When student perceptions are recognized, educators can provide lessons on relevant topics. Therefore, relevance is the main driver motivating students. Scientific literacy can be achieved if students understand and appreciate science and their work (Ajayi, 2018). Bybee and McCrae (2011) explained that perceptions of science play an important role in scientific literacy. Several researchers have included these aspects of perception as components of scientific literacy (Blanco-López et al., 2015; Choi et al., 2011). For example, Mun et al. (2015) used it to compile and establish a factor in the perception of scientific literacy. Thus, it is clear that prospective science teachers' perceptions of scientific literacy need to be identified.

This study aims to develop an instrument in the form of a questionnaire to measure prospective science teachers' perceptions of scientific literacy. The instruments developed are related to scientific literacy skills that have been developed by Hardinata and Permanasari (2017), Rusilowati et al. (2018), and Ani Rusilowati et al. (2016). When examining scientific literacy in the higher education system in Indonesia, especially in science teacher education programs, one crucial point known to researchers is the low awareness of instruments as a key tool for measuring the development of scientific literacy in prospective science teachers. Several international studies have examined the perceptions of scientific literacy, albeit not specifically related to science teacher candidates, such as the analysis of Mun et al. (2015). Studies on this issue have rarely been conducted for Indonesia. Information obtained from this research would help universities grasp the extent of students' perceptions of scientific literacy. Understanding students' scientific literacy perceptions can provide a benchmark for developing graduate competency standards, the curriculum, teaching models, and an evaluation of learning outcomes in science teacher education programs in Indonesia.

\section{METHOD}

This study used mixed methods to develop the instrument in the form of a questionnaire to measure prospective science teachers' perceptions of scientific literacy. This instrument was developed in the following four stages. Stage 1 developed domains and items. Stage 2 involved the expert validation and exploratory factor analysis (EFA), and testing content validity and data reduction. Stage 3 examined the construct validity and internal consistency of the questionnaire produced with confirmatory factor analysis (CFA).

\section{Stage 1: Development of Domains and Items}

In the stages of item preparation, a literature search was carried out with the keywords "prospective science teachers," "scientific literacy," and "perception." The central database in this study contained reputable national and international journals in education, especially in the Asian region, and theses and dissertations were used as inputs in this study. The literature review was carried out by including all relevant theoretical and empirical literature sources across various research methods. The literature review also focused on instruments related to the perception of scientific literacy developed by researchers.

Several scientific literacy and instrument development experts at three leading universities in East Java were involved in thematic coding from various selected sources through a focus group discussion. This step was taken to determine the domain in the perception of students' scientific literacy, measured through a questionnaire. Based on the input of some experts, two main studies were adapted to determine the domain that influences scientific literacy: the GSLQ developed by Mun et al. (2015), which presented intrinsic factors; and the Science Curriculum Implementation Questionnaire developed by Sharp et al. (2011), which presented extrinsic factors.

At the end of this stage, the scientific literacy questionnaire was divided into 77 questionnaires in seven main domains: thinking habits (15 items), character and values (9 items), science as a human endeavor (14 items), metacognition (13 items), interest and views on science (9 items), ethics in science ( 6 items), and teaching scientific literacy (11 items). The questionnaire was compiled using a Likert scale 
consisting of six items: $1=$ strongly disagree, $2=$ disagree, $3=$ somewhat disagree, $4=$ somewhat agree, $5=$ agree, and $6=$ strongly agree.

\section{Stage 2: Expert Validation and Exploratory Factor Analysis, and Testing Content Validity and Data Reduction}

This stage was performed under expert validation and EFA. EFA continues to be carried out because only some studies have directly adopted the statement items developed by Fan et al. (2018) and Mun et al. (2015). In our study, this stage was carried out to obtain a complete questionnaire to measure scientific literacy perceptions from prospective science teachers.

\section{Participants}

Participants in the study consisted of 808 third-year science education students from several universities in East Java Province, Indonesia: 132 students from the Nusantara PGRI Kediri University, 332 students from Jember State University, 352 students from Surabaya State University, 360 students from Malang State University, and 440 students from the University of Muhammadiyah Malang. The final sample from five institutions of which $18.8 \%(n=152)$ were men and $81.2 \%$ $(n=656)$ were women and average. Respondents' ages ranged between 20 and 21 . The participants were divided into two subsamples of the same number. Sample selection was carried out using the purposive cluster sampling technique, taking into account the status of universities (i.e., state or private) and the quality of higher education based on the college cluster, according to the Ministry of Research and Higher Education, Indonesia. The selection of samples from various universities with different statuses and qualities enabled us to control different effects, owing to each university's unique academic situation (Brown, 2002). In this study, the questionnaires distributed reached 1000 units, and 808 questionnaires were returned, giving a response rate of $80.8 \%$. This far exceeds the minimum number of 100 needed in factor analysis research, according to Dörnyei (2003), and 150, according to Tabachnick and Fidell (2007).

\section{Procedure}

First, we applied for approval of the research from the head of the science education department at the participating universities while providing information about the research protocol and the questionnaire developed. After obtaining permission from the relevant department, data collection was carried out directly on each campus in a schedule determined by each department. We explained to the department lecturers in their capacity as prospective science teachers that research was being carried out to examine students' perceptions of scientific literacy. The students were invited to participate voluntarily. They were asked to complete the prepared questionnaire. The responses were kept confidential and anonymous. Respondents were allowed to ask questions before answering the survey.

\section{Expert validation and exploratory factor analysis}

A draft produced in Stage 1 was given to the expert panel for review to determine its validity. In this study, the panel of experts consisted of three scientific literacy experts and three experts in instrument development. These six experts were asked to qualitatively assess the content validity of each item in the questionnaire. The experts assessed the questionnaire's statements to ensure that they were easy to understand and that respondents would be unlikely to encounter difficulties or provide ambiguous answers. In addition, the experts assessed whether the questionnaire items matched the construct to be measured and whether the questions were repetitive. The experts were asked to choose one of the three options used: suitable, correct, or does not match/delete. Their responses to the questionnaire items were used to refine the questionnaire comprehensively.

The content validity ratio (CVR) was calculated for each item in the questionnaire from the expert responses. Questionnaire items with a CVR below 0.80 were issued. In total, 17 items were issued: thinking habits (three items), characters and values (three items), science as a human endeavor (six items), metacognition (one item), ethics in science (one item), and teaching literacy scientific (three items). The final results of this stage consisted of 60 items in the questionnaire. Meanwhile, the experts suggested two items be corrected: the teaching factor of scientific literacy, because they considered it unclear; and whether scientific literacy was a subject or should be integrated into science subjects.

\section{Testing content validity and data reduction}

Content validity and data reduction were tested by examining students' responses to the questionnaires. Descriptive statistics were used to analyze the scores obtained (mean and standard deviation) and item-total correlation (Pearson's product-moment correlation coefficient). EFA reduced items by identifying interrelated items and eliminating items that had a confusing or identical meaning. The final item reduction stage produced a comprehensive questionnaire wherein the available domains obtained were the underlying factors and broadly reflected the perceptions of prospective science teachers' scientific literacy.

Using principal component analysis of factors, the number of general domains was determined based on an eigenvalue $>1$. The rotation method employed Varimax with Kaiser normalization. In this study, item reduction was carried out if the rotated factor loading was lower 
than 0.50 or indicated cross-loading. In addition, if the public domain contained only one questionnaire, the item was deleted, ensuring at least two questionnaires in each public domain.

\section{Construct Validity and Internal Consistency with Confirmatory Factor Analysis}

This stage accurately identified the general domain of the number of items obtained from the data reduction process using CFA. Maximum likelihood estimation was used to assess the model fit according to the covariance matrix.

Some commonly used data match indexes are the chisquare goodness test $(x 2 / d f)$, root mean square error from approximation (RMSEA), goodness-of-fit index (GFI), adjusted goodness-of-fit index (AGFI), comparative fit index (CFI), and Tucker-Lewis index (TLI). In general, the criteria for determining the model fit are $\chi 2 / \mathrm{df} \leq 3.00$ and RMSEA of $\leq 0.08$ (Schumacker \& Lomax, 2010; Tabachnick \& Fidell, 2007); and GFI, AGFI, CFI, and TLI close to 0.90 indicating acceptable fit while that $\geq 0.9$ indicating good fit (McCoach et al., 2013)

Cronbach's alpha, composite reliability (CR), and average variance extracted (AVE) were also examined to guarantee the questionnaire items' internal consistency. (Hair, 2010) recommended that the values for Cronbach's alpha be $\geq 0.6, \quad \mathrm{CR} \geq 0.7$, and AVE $\geq 0.5$. However, several studies, such as Huang et al. (2017) and Ahmad et al. (2016), have used $C R \geq 0.6$. An examination of concurrent validity was also performed in this study by correlating between eight domains and total scores.

\section{RESULTS}

Based on the results of item analysis, it is known that the average questionnaire items are in the range of 3.47 to 5.67 (SD from 0.63 to 1.56). Pearson's product-moment correlation coefficient starts from 0.19 to 0.63 , with a significance of $0.000<0.01$. Only one item was below 0.2 , but after considering the p-value, all items in the scientific literacy perception questionnaire were maintained at this stage. In item reduction using EFA (Table 1), 16 questionnaire items were issued from 60 items in the questionnaire. The results were 44 items and eight available domains with eigenvalues greater than 1 .

The measurement of sample adequacy with the Kaiser-Meyer-Olkin (KMO) test was 0.921. Based on the KMO criteria from (Kaiser, 1970), the sample's adequacy in the study included the category of "marvelous-great." The eight domains accounted for $50.38 \%$ of the total variance. In social science research, total variance in the range of $40-60 \%$ is considered acceptable. These results meet the requirement of at least $40 \%$ of the total variance described by (Kline, 1994). In addition, the Bartlett sphericity test was significant (chi-square=1051.4, $\underline{\text { Table 1. Exploratory factor analyses of } 44 \text { items }}$

\begin{tabular}{|c|c|c|c|c|c|c|c|c|}
\hline \multirow{2}{*}{ Domain } & \multicolumn{8}{|c|}{ Component } \\
\hline & 1 & 2 & 3 & 4 & 5 & 6 & 7 & 8 \\
\hline \multicolumn{9}{|c|}{ Metacognitive (M) } \\
\hline M1 & 0.687 & & & & & & & \\
\hline M2 & 0.655 & & & & & & & \\
\hline M3 & 0.612 & & & & & & & \\
\hline M4 & 0.598 & & & & & & & \\
\hline M5 & 0.565 & & & & & & & \\
\hline M6 & 0.556 & & & & & & & \\
\hline M7 & 0.505 & & & & & & & \\
\hline
\end{tabular}

Nature and function of science (NFS)

$\begin{array}{ll}\text { NFS1 } & 0.704 \\ \text { NFS2 } & 0.673 \\ \text { NFS3 } & 0.655 \\ \text { NFS4 } & 0.644 \\ \text { NFS5 } & 0.642 \\ \text { NFS6 } & 0.621 \\ \text { NFS7 } & 0.586 \\ \text { NFS8 } & 0.566 \\ \text { NFS9 } & 0.550\end{array}$

Science as human endeavor (SHE)

SHE1 0.772

SHE2 $\quad 0.688$

SHE3 $\quad 0.659$

SHE4 0.623

SHE5 $\quad 0.547$

Habits of mind (HM)

$\begin{array}{ll}\text { HM1 } & 0.707 \\ \text { HM2 } & 0.696 \\ \text { HM3 } & 0.621 \\ \text { HM4 } & 0.616 \\ \text { HM5 } & 0.541 \\ \text { terest in science (IS) } & \end{array}$

Interest in science (IS)

IS1 0.625

IS2 0.600

IS3 0.594

IS4 0.539

IS5 0.518

The teaching of scientific literacy (TSL)

$\begin{array}{ll}\text { TSL1 } & 0.648 \\ \text { TSL2 } & 0.610 \\ \text { TSL3 } & 0.610 \\ \text { TSL4 } & 0.568 \\ \text { TSL5 } & 0.566\end{array}$

A sense of moral and social responsibility (MSR)

MSR1

MSR2

0.678

MSR3

0.669

MSR4

0.616

Ethics in science (ES)

ES1

0.779

ES2

0.778

ES3

ES4

0.562

$\begin{array}{lllllllll}\text { Eigenvalue } & 14.88 & 4.74 & 2.29 & 1.90 & 1.81 & 1.69 & 1.49 & 1.42\end{array}$ $\begin{array}{llllllllll}\text { \% Variance } & 24.81 & 7.91 & 3.81 & 2.15 & 3.01 & 2.81 & 2.49 & 2.36\end{array}$ Cumulative \% 24.8123 .7236 .5339 .7042 .7145 .5248 .0150 .38

Note: Only factor loadings greater than 0.50 are reported

$\mathrm{p}<0.01)$, meaning that the data had normal multivariate distribution. 


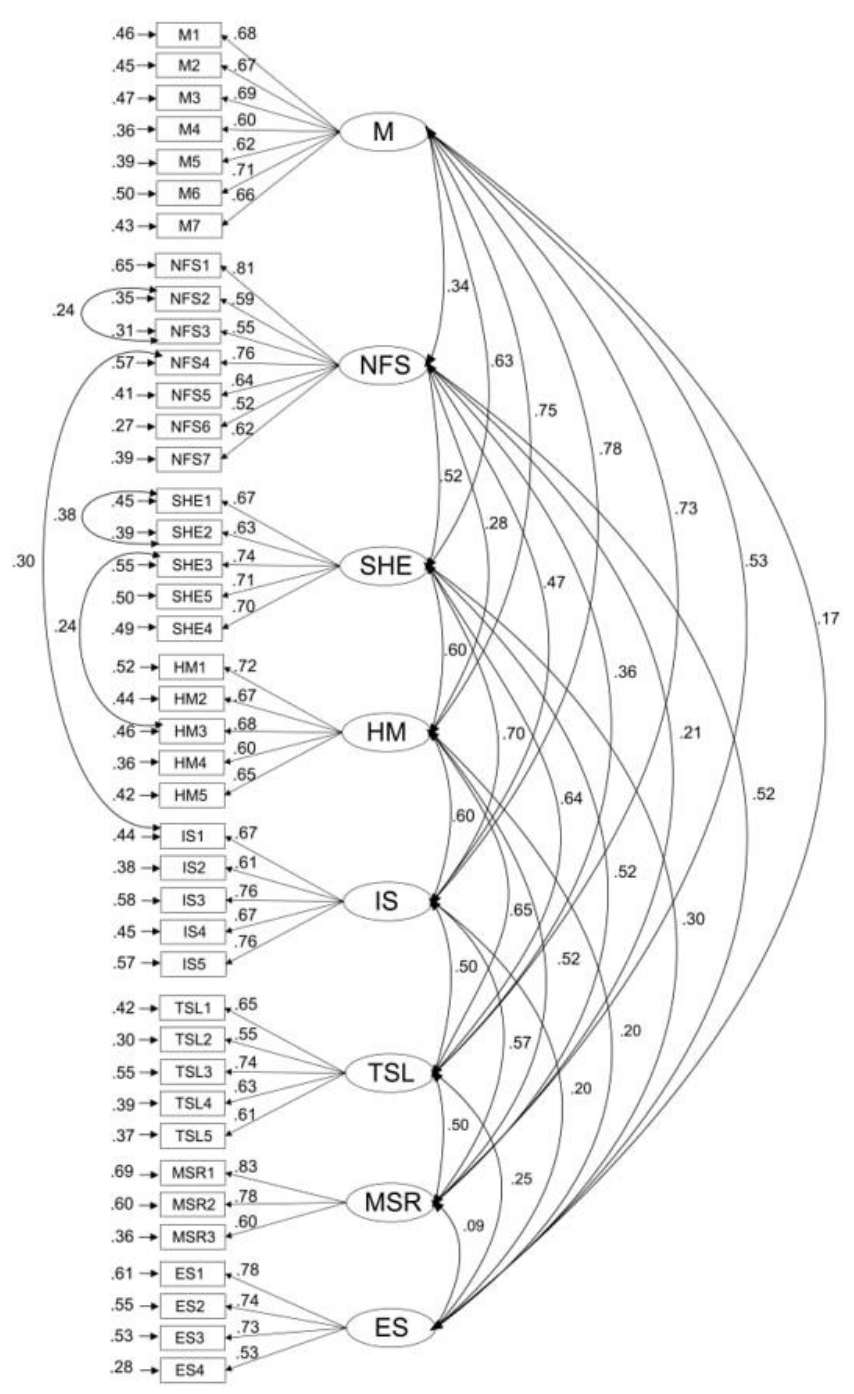

Figure 1. Confirmatory factor analysis with the correlated model

Forty-four items of questionnaires produced from the reduction stages with EFA were then tested with CFA to determine the suitability of the model. The results were acceptable but relatively poor, with goodness-of-fit statistics as follows: $\chi 2 / \mathrm{df}=1,529.638 / 873, \mathrm{p}<0.001$, RMSEA $=0.043, \mathrm{GFI}=0.846, \mathrm{AGFI}=0.825, \mathrm{CFI}=0.905$, and TLI $=0.897$. Examination of the value of standardized regression weights shows that there are 3 items out of 44 that have values less than 0.5 . The results of the CFA test on 41 items produced a better fit model, although the results of GFI and AGFI still did not reach 0.90: $\chi^{2} / \mathrm{df}=1,215.391 / 744, \mathrm{p}<0.001$, RMSEA=0.040, GFI= 0.868, AGFI=0.847, CFI=0.929, TLI=0.921 (Figure 1).

In this study, CFA was obtained with correlated capital and eight domains (Figure 1) compared with the

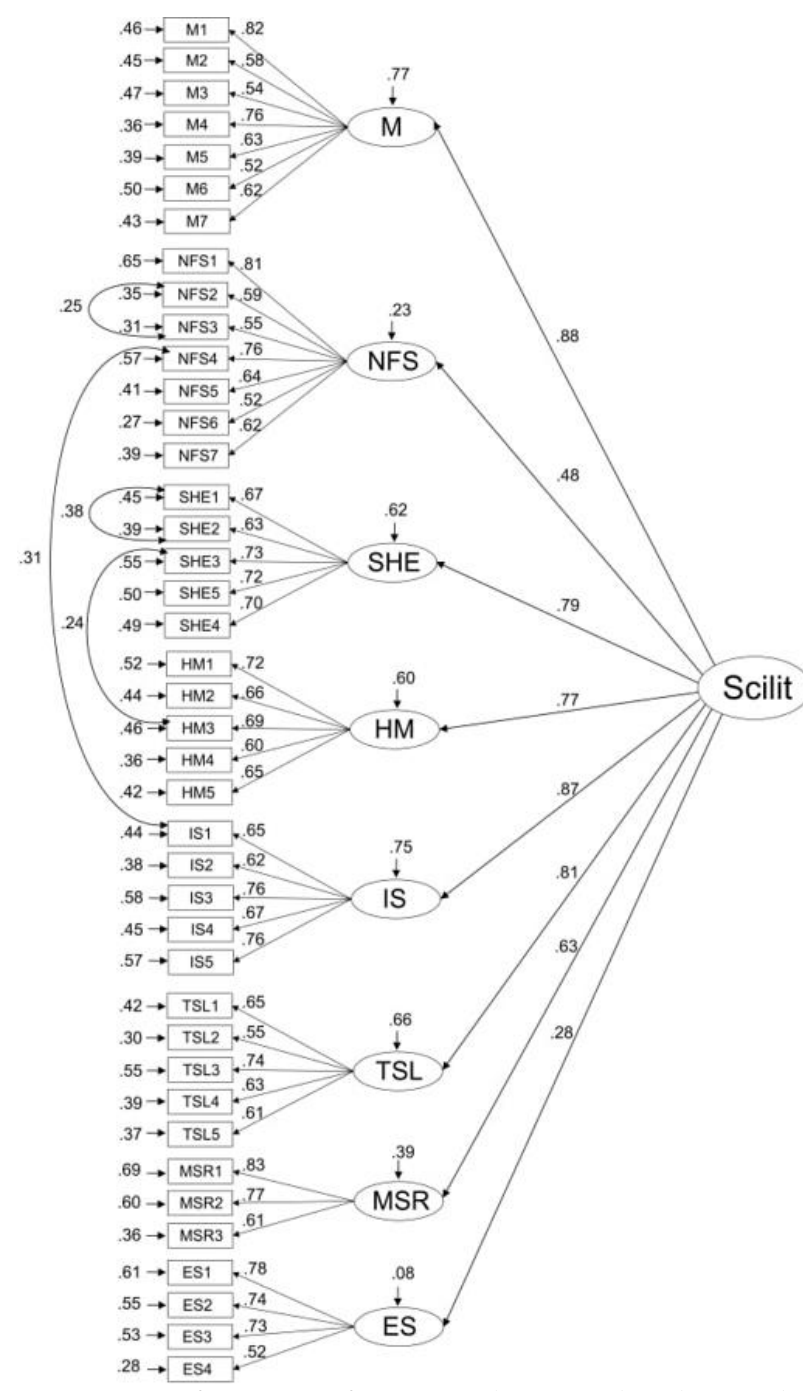

Figure 2. Confirmatory factor analysis with a hierarchical model

other four-factor model conceptualization. The CFA results with the five types of models (Table 2) showed a very high increase when testing the uncorrelated factor model compared to the one-factor model and the zerofactor model (null). Nevertheless, both the one-factor and the uncorrelated-factor model are still categorized as "bad" when viewed from the goodness-of-fit statistics.

Meanwhile, the hierarchical model was maintained as a model with an almost identical match to the correlated factors. These results indicate that the eight general domains identified were interrelated with firstlevel domains and that all were related to second-level domains, called perceptions of scientific literacy. This model supports the assumption that the public domain is part of a larger domain of scientific literacy (Figure 2).

Table 2. Confirmatory factor analysis of prospective science teachers based on the scientific literacy questionnaire

\begin{tabular}{lcccccccc}
\hline Model & $x^{2}$ & $d f$ & $\chi 2 / d f$ & GFI & AGFI & CFI & TLI & RMSEA \\
\hline Null & $7,417.201$ & 820 & 9.045 & 0.246 & 0.208 & 0.000 & 0.000 & 0.141 \\
One factor & $3,395.391$ & 778 & 4.346 & 0.622 & 0.582 & 0.603 & 0.582 & 0.091 \\
Uncorrelated factor & $2,404.191$ & 775 & 3.102 & 0.722 & 0.691 & 0.753 & 0.739 & 0.072 \\
Correlated factor & $1,214.391$ & 744 & 1.634 & 0.868 & 0.847 & 0.929 & 0.921 & 0.040 \\
Hierarchical & $1,343.024$ & 766 & 1.753 & 0.854 & 0.836 & 0.913 & 0.906 & 0.043 \\
\hline
\end{tabular}


Table 3. The 41-item eight-factor perceptions of prospective science teachers from the scientific literacy questionnaire

\begin{tabular}{|c|c|c|c|}
\hline \multirow{2}{*}{ Domain/item } & \multicolumn{3}{|c|}{ Criteria } \\
\hline & $\lambda$ & CR & AVE \\
\hline \multicolumn{4}{|c|}{ Metacognitive (M) } \\
\hline M1 & 0.687 & 0.84 & 0.44 \\
\hline M2 & 0.655 & & \\
\hline M3 & 0.612 & & \\
\hline M4 & 0.598 & & \\
\hline M5 & 0.565 & & \\
\hline M6 & 0.556 & & \\
\hline M7 & 0.505 & & \\
\hline \multicolumn{4}{|c|}{ Nature and function of science (NFS) } \\
\hline NFS1 & 0.81 & 0.83 & 0.42 \\
\hline NFS2 & 0.59 & & \\
\hline NFS3 & 0.53 & & \\
\hline NFS4 & 0.76 & & \\
\hline NFS5 & 0.64 & & \\
\hline NFS6 & 0.52 & & \\
\hline NFS7 & 0.62 & & \\
\hline \multicolumn{4}{|c|}{ Science as human endeavor (SHE) } \\
\hline SHE1 & 0.68 & 0.82 & 0.48 \\
\hline SHE2 & 0.63 & & \\
\hline SHE3 & 0.73 & & \\
\hline SHE4 & 0.70 & & \\
\hline SHE5 & 0.71 & & \\
\hline \multicolumn{4}{|c|}{ Habits of mind (HM) } \\
\hline HM1 & 0.72 & 0.80 & 0.44 \\
\hline HM2 & 0.67 & & \\
\hline HM3 & 0.68 & & \\
\hline HM4 & 0.60 & & \\
\hline HM5 & 0.65 & & \\
\hline \multicolumn{4}{|c|}{ Interest in science (IS) } \\
\hline IS1 & 0.67 & 0.82 & 0.49 \\
\hline IS2 & 0.62 & & \\
\hline IS3 & 0.76 & & \\
\hline IS4 & 0.67 & & \\
\hline IS5 & 0.76 & & \\
\hline \multicolumn{4}{|c|}{ The teaching of scientific literacy (TSL) } \\
\hline TSL1 & 0.65 & 0.77 & 0.41 \\
\hline TSL2 & 0.55 & & \\
\hline TSL3 & 0.74 & & \\
\hline TSL4 & 0.63 & & \\
\hline TSL5 & 0.61 & & \\
\hline \multicolumn{4}{|c|}{ A sense of moral and social responsibility (MSR) } \\
\hline MSR1 & 0.83 & 0.78 & 0.55 \\
\hline MSR2 & 0.78 & & \\
\hline MSR3 & 0.60 & & \\
\hline \multicolumn{4}{|c|}{ Ethics in science (ES) } \\
\hline ES1 & 0.78 & & \\
\hline ES2 & 0.74 & 0.79 & 0.49 \\
\hline ES3 & 0.73 & & \\
\hline ES4 & 0.53 & & \\
\hline
\end{tabular}

Therefore, eight public domains can be given separately or combined into one large domain. The results of the CFA with hierarchical models show that most have a strong path coefficient. The most robust domain is domain 1 , equal to 0.88 , followed by domain 6 , which has almost the same coefficient, that is, 0.81 , while the
Table 4. Cronbach's alpha of eight domain perceptions of prospective science teachers from the scientific literacy questionnaire

\begin{tabular}{lcc} 
Domain & $\mathrm{N}$ & $\begin{array}{c}\text { Cronbach's } \\
\text { alpha (a) }\end{array}$ \\
\hline Metacognition & 7 & 0.84 \\
The nature and function of science & 7 & 0.84 \\
Science as human endeavor & 5 & 0.83 \\
Habits of mind & 5 & 0.80 \\
Interest in science & 5 & 0.82 \\
The teaching of scientific literacy & 5 & 0.77 \\
A sense of moral and social & 3 & 0.77 \\
responsibility & & \\
Ethics in Science & 4 & 0.79 \\
Total & 41 & 0.92 \\
\hline
\end{tabular}

weakest domain is domain 8 , with a path coefficient of 0.28 .

Hair (2010) recommended using the validity of other criteria besides evaluating fit models to obtain a bigger picture of each item's parameter. In this study, three criteria were used: item quality $(\lambda)$ obtained from standardized regression weights, composite reliability $(\mathrm{CR})$, and average variance extracted (AVE), as presented in Table 3. Grain quality values $(\lambda)$ indicated that all factors had a value greater than 0.50. These results indicate that the observed variables adequately reflect the construct's latent variables (Tabachnick \& Fidell, 2007).

Judging from the $C R$ value, the test results showed a range of $0.77-0.84$. These results indicated that in terms of $\mathrm{CR}$, all identified public domains were met according to the recommendations of Hair (2010). Most public domains did not match the AVE criteria, and were below 0.5 . Only factor 7 had a higher value, of 0.55 . However, according to Fornell and Larcker (1981), this value still has good strength.

The Cronbach's alpha test on 41 items with eight domains (Table 4) showed promising results and fell within values ranging from 0.77 to 0.84 ; the overall value was 0.92 . These results indicate that the questionnaire had high reliability in terms of each domain and the entire domain.

Table 5 presents estimates of the Pearson correlation of all domains. The results of this test show that almost all the domains were strongly correlated with each other and the total score. In addition, it appears that correlation with domain 8 was the weakest; even the correlation between domains 7 and 8 was not significant. Overall, this estimate followed the correlated factor model proposed in this study.

\section{DISCUSSION AND CONCLUSIONS}

This research was conducted to develop and validate instruments and scientific literacy questionnaires and to diagnose the perceptions of prospective science teachers 
Table 5. Correlations between eight domains and the total score

\begin{tabular}{|c|c|c|c|c|c|c|c|c|c|}
\hline & $\mathrm{M}$ & NFS & SHE & $\mathrm{HM}$ & IS & TSL & MSR & ES & \\
\hline $\mathrm{M}$ & 1 & & & & & & & & \\
\hline NFS & $0.286^{* *}$ & 1 & & & & & & & \\
\hline SHE & $0.520^{* *}$ & $0.425^{* *}$ & 1 & & & & & & \\
\hline HM & $0.618^{* *}$ & $0.198^{* *}$ & $0.488^{* *}$ & 1 & & & & & \\
\hline IS & $0.642^{* *}$ & $0.356^{* *}$ & 0.560 ** & $0.483^{* *}$ & 1 & & & & \\
\hline TSL & $0.580^{* *}$ & $0.255^{\star *}$ & $0.490^{* *}$ & $0.591^{* *}$ & $0.532^{* *}$ & 1 & & & \\
\hline MSR & $0.441^{* *}$ & $0.173^{* *}$ & $0.422^{* *}$ & $0.429 * *$ & $0.462^{* *}$ & $0.396^{* *}$ & 1 & & \\
\hline ES & $0.153^{* *}$ & $0.452^{* *}$ & $0.252^{* *}$ & $0.180^{* *}$ & $0.151^{* *}$ & $0.206^{* *}$ & 0.063 & 1 & \\
\hline Total & $0.731^{* *}$ & $0.724^{* *}$ & $0.732^{* *}$ & $0.641^{* *}$ & $0.726^{* *}$ & $0.672^{* *}$ & $0.532^{* *}$ & $0.551^{* *}$ & 1 \\
\hline
\end{tabular}

Note: ${ }^{* *} p<0.01, \mathrm{M}=$ metacognition, NFS=the nature and function of science, SHE=science as a human endeavor, HM=habits of mind, IS=interest in science, TSL=teaching of scientific literacy, MSR=a sense of moral and social responsibility, and $\mathrm{ES}=\mathrm{ethics}$ in science

about scientific literacy and their teaching as future teacher candidates using questionnaires in the Indonesian population. The questionnaire development involved a rigorous statistical and psychometric process to ensure that the instruments were valid and reliable. Teacher perceptions are fundamental and contribute significantly to the effective implementation of learning effectively (Konokman et al., 2017). Contreras (2011) explained that teacher perceptions play a significant role in improving students' achievements and are needed to improve the education system. We believe that the instruments developed can add important information for future research regarding prospective science teachers' perceptions of scientific literacy and the teaching of scientific literacy in Indonesia.

\section{Domain and Questionnaire Item}

The analysis successfully identified eight domains: metacognition, the nature and function of science, science as a human endeavor, habits of mind, interest in science, the teaching of scientific literacy, a sense of moral and social responsibility, and ethics in science. The results of this study are similar to those of previous studies on the perception of scientific literacy carried out by Mun et al. (2015) and Choi et al. (2011). However, this questionnaire is slightly different, because it evaluates the perceptions of prospective science teachers. This is an essential step for science teacher students in Indonesia, given the rapid growth of scientific literacy in Indonesia over the last 5 years. Teaching scientific literacy in Indonesia no longer focuses on simply mastering the concepts and skills of basic scientific processes. Research reports on teaching integrate sociocultural problems to improve scientific literacy skills (Rahmasiwi et al., 2018; Rohmawati et al., 2018).

In addition, the questionnaire developed in this study included not only intrinsic factors but also extrinsic ones, such as teaching scientific literacy. As explained in the methods section, this instrument was developed to provide an alternative measurement of scientific literacy perceptions, because it covers both factor types. Given that extrinsic factors reflect the influence of the environment and academic context, and the fact that this instrument was developed by involving participants who have campus backgrounds of varying quality and status so that differential effects can be controlled, it is clear that if this instrument were used in different cultural environments, it could still be measured accurately.

The findings of previous studies support the items in this questionnaire. For example, "I use technology to support my learning process" illustrates the effectiveness of learning with technology integration, as found by Ghavifekr and Rosdy (2015). Integration of technology in learning is an effort that must be made to achieve scientific literacy in the digital era (Okada, 2013). Another item, "I do practicum/experiments/research projects in science learning in class," is also a key to success in teaching science-related material and to the teaching view of scientific literacy, according to Duit and Tesch (2010). This instrument can be said to provide an appropriate instrument to validate prospective science teachers' perceptions of scientific literacy and is supported by factor structure, reliability, and statistical validity.

CFA analysis with model hierarchy shows that metacognition has the highest path coefficient. By contrast, the domain of nature and science functions and the ethical domain in science have the lowest path coefficients. This result is different from that of Mun et al. (2015), who found that the metacognition domain has the lowest score and the nature of science domain the highest. In the Indonesian curriculum, especially in the 2013 revised curriculum, knowledge of metacognition was reinforced as the primary target at every level of education, from elementary school to high school (Herlanti et al., 2017). In addition, compared to research on the other seven domains, educational research related to metacognition has been one of the most popular topics of research for more than 40 years (Al-Jarrah et al., 2014; Ellis et al., 2014; Harrison \& Vallin, 2018). In Indonesia, many research reports related to metacognition have been published in the past decade, and most are associated with mastering concepts. Researchers assume 
this is what helps students develop good metacognition skills. Furthermore, Seraphin et al. (2012) revealed that the increase in teacher metacognition is directly proportional to the increase in students' scientific literacy. This statement explains the favorable conditions in the findings of this study that science teacher students in Indonesia with good metacognition skills will go on to teach good scientific literacy.

In terms of the dimensions of the nature and function of science, there is limited research on teaching that results in students" views of "the nature and function of science. Of the works on this topic, the latest research conducted by Wicaksono et al. (2018) found that students still have meagre ability to comprehend the nature of science. At lower levels of education, such as junior high school, Sofiani and Mudzakir (2018) showed that students still do not have an appropriate good view of the nature of science and advised teachers to emphasize the nature of science in their teaching. Meanwhile, Khery et al. (2018) found that the views of prospective science teachers on the nature of science were not good, because lecturers rarely convey all aspects of the nature of science in the lecture process. A number of these reports have confirmed the results of this study, showing that the dimensions of the nature and function of science in scientific literacy make a low contribution.

In terms of ethical dimensions in science, the concept of ethics plays a small role in modern scientific inquiry and technological development (Richards, 2012). In Indonesia, most lecturers and researchers at various universities have understood and considered the importance of research ethics committees, although there is still misunderstanding about the tasks and functions (Fourianalistyawati et al., 2018). Scientific research and academia are often tainted by data fabrication, plagiarism, and other unethical practices (Sharma, 2015). The lack of standard ethical standards as a guide for conducting research is also a dilemma for scientists (Fouka \& Mantzorou, 2011). Therefore, civil society as part of the global community should find solutions that can be accepted by all parties, including scientists.

\section{Factorial Validity and Questionnaire Reliability}

This research attempts to develop and validate a questionnaire on perceptions of scientific literacy for prospective science teachers using two analyses, EFA and CFA. The sample size in the study using these analyses is very important and determines which results can be accounted for (Meyers et al., 2017). By this method, the adequacy of the number of samples described meets the threshold of more than 150 participants. The measurement results with the KMO test also showed excellent results. The number of item questionnaires produced in this study was 41 (Appendix A), and thus, the ratio of participants to items fulfilled the maximum requirement of 10:1 (DeVellis, 2012). Of these various sizes, this study's sample size is considered large enough and sufficient to produce meaningful statistical power.

Cronbach's alpha coefficients are more significant than 0.80 for all items and most domains; these results indicate the reliability of the overall acceptable items in this questionnaire (Meyers et al., 2017). Meanwhile, for domains that were less than 0.80, the Cronbach's alpha coefficient was more significant than 0.60 . According to Hair (2010), this result still represents reliability. Thus, viewed from each domain and overall, this questionnaire can be relied in future research on the topic. In addition, the questionnaire's internal consistency was strengthened by an analysis of the validity of the correlation between the eight domains. The results of the validity analysis revealed that the relationships between the domains were classified as moderate. This result indicates that each domain is still related to the others, even though the domains are different. These results imply that the domains can be used separately or together as an assessment tool for educational and research purposes. Although a domain can be used separately, researchers suggest using a model of all eight domains to obtain a more comprehensive picture of prospective teachers' scientific perceptions.

In this study, several items classified as negative statements were removed owing to low loading factors. Meanwhile, several other items were grouped into one domain. Some studies report that including negative statements in questionnaires risks generating results with low ambiguity and reliability (Roszkowski \& Soven, 2010). Nonetheless, this practice is carried out in this study to reduce the bias of participants' responses (Groves et al., 2009). From the perspective of the age of participants, negative statements are eminently suitable because they reflect the response style among adults (DiStefano \& Motl, 2006), although another study by Tomás et al. (2013) showed that there is no connection between negative statements and the age of participants. Future research should re-examine the negative questions, one of which could be answered by separating the negative statement items into different domains (Ye \& Wallace, 2014).

In summary, this study results showed 41 questionnaire items and eight domains with acceptable internal validity and consistency: metacognition (seven items), the nature and function of science (seven items), science as a human endeavour (five items), habits of mind (five items), interest in science (five items), the teaching of scientific literacy (five items), a sense of moral and social responsibility (three items), and ethics in science (four items). Validity and reliability were tested using EFA and CFA. The results of this study are similar to those of previous studies on the GSLQ developed by Mun et al. (2015) and the Science 
Curriculum Implementation Questionnaire developed by Sharp et al. (2011).

\section{Implications and Limitations}

This research has the following theoretical and practical implications for the perception of scientific literacy in the context of prospective science teachers in Indonesia. Other researchers can use the questionnaire we developed and validated on perceptions of scientific literacy to find domains that contribute to prospective science teachers' scientific literacy skills. Information obtained from this study could help improve scientific literacy skills through science teacher education programs. Policymakers and material developers for lectures in science teacher education courses could refer to this study's results by considering the domains of scientific literacy identified.

The use and measurement of prospective science teacher students could help faculty quickly identify whether the program has effectively formed adequate perceptions of scientific literacy. Finally, this instrument can be used to measure standardized scientific literacy perceptions for educational and research purposes.

The limitations of this study are as follows. First, the questionnaire instrument developed in this study focuses on the scientific literacy of prospective science teachers in Indonesia. However, this instrument could still accurately measure other populations, including those in other countries. Re-validation is needed to improve the validity and reliability of the instrument.

Second, this study did not reveal comparability between samples (e.g., gender, level/semester, and university status/quality). Future research should compare samples to examine whether there are differences in perceptions between men and women, third-year and first-year students, and students from public and private universities.

Third, even though the value of GFI and AGFI approached the threshold value and was still considered acceptable, further research should be carried out to improve the goodness-of-fit statistics. Questions that have low internal consistency, with low AVE, and/or are classified as negative statements must be revised, added, modified, or deleted to improve the consistency and reliability of the questionnaire instruments on this perception of scientific literacy. In addition, test-retest data are needed from time to time to develop the stability of scientific literacy perceptions, especially those of prospective science teachers, involving around 60 samples.

Author contributions: All authors have sufficiently contributed to the study, and agreed with the results and conclusions.

Funding: This work was supported by the Universitas Negeri Malang [5.3.472/UN32.14.1/LT/2021].

Acknowledgements: All authors are grateful to Lembaga Penelitian dan Pengabdian Masyarakat (LP2M) Universitas Negeri Malang (UM). All authors are also grateful to all biology education study programs for their participation in data collection and to all the participants who answered the questionnaire.

Declaration of interest: No conflict of interest is declared by authors.

\section{REFERENCES}

Ahmad, S., Zulkurnain, N., \& Khairushalimi, F. (2016). Assessing the validity and reliability of a measurement model in structural equation modeling (SEM). British Journal of Mathematics \& Computer Science, 15(3), 1-8. https://doi.org/ 10.9734/BJMCS/2016/25183

Ajayi, V. O. (2018). Scientific literacy. https://doi.org/ 10.13140/rg.2.2.13345.92009

Al Sultan, A., Henson, H., \& Fadde, P. J. (2018). Preservice elementary teachers' scientific literacy and self-efficacy in teaching science. IAFOR Journal of Education, 6(1), 25-42. https://doi.org/10.22492/ ije.6.1.02

Alebous, T. (2013). Science teaching and level of the scientific literacy of the primary school teacher in Jordan. International Journal for Cross-Disciplinary Subjects in Education, 4(2), 1190-1196. https:// doi.org/10.20533/ijcdse.2042.6364.2013.01 67

Al-Jarrah, T. M., Mansor, N., Talafhah, R. H., \& AlJarrah, J. M. (2014). A review of research into metacognitive strategies in the process of education: Teaching and learning of English skills. International Journal of Current Research, 10(12), 76832-76838.

https:// doi.org/10.24941/ijcr.33608.12.2018

Al-Momani, F. N. N. (2016). Assessing the development of scientific literacy among undergraduates college of education. Journal of Studies in Education, 6(2), 199-212. https:/ / doi.org/10.5296/jse.v6i2.9405

Ardianto, D., \& Rubini, B. (2016). Comparison of students' scientific literacy in integrated science learning through model of guided discovery and problem based learning. Jurnal Pendidikan IPA Indonesia [Indonesian Science Education Journal], 5(1), 31-37. https:// doi.org/10.15294/jpii.v5i1.5786

Basam, F., Rusilowati, A., \& Ridlo, S. (2017). Analysis of science literacy learning with scientific inquiry approach in increasing science competence of students. Journal of Primary Education, 6(3), 174-184. https:// doi.org/10.15294/JPE.V6I3.21049

Blanco-López, Á., España-Ramos, E., González-García, F. J., \& Franco-Mariscal, A. J. (2015). Key aspects of scientific competence for citizenship: A Delphi study of the expert community in Spain. Journal of Research in Science Teaching, 52(2), 164-198. https:/ / doi.org/10.1002/tea.21188

Brown, H. D. (2002). English language teaching in the "post-method" era: Toward better diagnosis, 
treatment, and assessment. In J. C. Richards, \& W. A. Renandya (Eds.), Methodology in language teaching (pp. 9-18). Cambridge University Press. https://doi.org/10.1017/CBO9780511667190.003

Bybee, R., \& McCrae, B. (2011). Scientific literacy and student attitudes: Perspectives from PISA 2006 science. International Journal of Science Education, 33(1), 7-26. https://doi.org/10.1080/09500693. 2010.518644

Cavas, P. H., Ozdem, Y., Cavas, B., Cakiroglu, J., \& Ertepinar, H. (2013). Turkish pre-service elementary science teachers' scientific literacy level and attitudes toward science. Science Education International, 24(4), 383-401.

Choi, K., Lee, H., Shin, N., Kim, S.-W., \& Krajcik, J. (2011). Re-conceptualization of scientific literacy in South Korea for the 21st century. Journal of Research in Science Teaching, 48(6), 670-697. https:/ / doi.org/ 10.1002/tea.20424

Contreras, M. E. (2011). The effects of teacher perceptions and expectations on student achievement. University of California.

Davies, R., \& Priestley, C. (2017). Landscape survey of science literacy in developing countries: Summary report | Agricultural Information Management Standards (AIMS) [Summary Report]. Network for Information and Digital Access. http://aims. fao.org/activity/blog/landscape-survey-scienceliteracy-developing-countries-summary-report

DeVellis, R. F. (2012). Scale development: Theory and applications. SAGE.

DiStefano, C., \& Motl, R. W. (2006). Further investigating method effects associated with negatively worded items on self-report surveys. Structural Equation Modeling: A Multidisciplinary Journal, 13(3), 440-464. https://doi.org/10.1207/s15328007sem1303_6

Dörnyei, Z. (2003). Questionnaires in second language research: Construction, administration, and processing. Lawrence Erlbaum Associates.

Duit, R., \& Tesch, M. (2010). On the role of the experiment in science teaching and learningVisions and the reality of instructional practice. Proceedings of the 7th International Conference on Hands-on Science, 17-30.

Ellis, A. K., Denton, D. W., \& Bond, J. B. (2014). An analysis of research on metacognitive teaching strategies. Procedia-Social and Behavioral Sciences, 116, 4015-4024. https://doi.org/10.1016/j.sbspro. 2014.01 .883

Faisal, \& Martin, S. N. (2019). Science education in Indonesia: Past, present, and future. Asia-Pacific Science Education, 5(1), Article number 4. https: / / doi.org/10.1186/s41029-019-0032-0

Fakhriyah, F., Masfuah, S., Roysa, M., Rusilowati, A., \& Rahayu, E. S. (2017). Student's science literacy in the aspect of content science? Jurnal Pendidikan IPA Indonesia [Indonesian Science Education Journal], 6(1), 81-87. https:/ / doi.org/10.15294/jpii.v6i1.7245

Fan, Y., Keating, X. D., Liu, J., Zhou, K., Shangguan, R., \& Knipe, R. (2018). Development of a scale measuring Chinese preservice physical education teachers' beliefs about the physical education profession. The Asia-Pacific Education Researcher, 27(5), 365-372. https://doi.org/10.1007/s40299018-0395-0

Fornell, C., \& Larcker, D. F. (1981). Evaluating structural equation models with unobservable variables and measurement error. Journal of Marketing Research, 18(1), 39. https:/ / doi.org/10.2307/3151312

Fouka, G., \& Mantzorou, M. (2011). What are the major ethical issues in conducting research? Is there a conflict between the research ethics and the nature of nursing? Health Science Journal, 5(1), 1-14.

Fourianalistyawati, E., Uswatunnisa, A., Mahdiannur, M. A., Saleky, A. P., Soebandhi, S., Reni, A., \& Kurniasih, N. (2018). Research development in Indonesia: Ethics committee in open science and collaboration era. Journal of Physics: Conference Series, 1114, 1-9. https://doi.org/10.1088/17426596/1114/1/012069

Ghavifekr, S., \& Rosdy, W. A. W. (2015). Teaching and learning with technology: Effectiveness of ICT integration in schools. International Journal of Research in Education and Science, 1(2), 175-191. https:// doi.org/10.21890/ijres.23596

Groves, R. M., Fowler, F. J. Jr., Couper, M. P., Lepkowski, J. M., Singer, E., \& Tourangeau, R. (Eds.). (2009). Survey methodology. Wiley.

Hair, J. F. (Ed.). (2010). Multivariate data analysis. Pearson Prentice Hall.

Hardinata, A., \& Permanasari, A. (2017). Development and validation of a scientific literacy test on global warming theme. Proceedings of the 2016 International Conference on Mathematics and Science Education. International Conference on Mathematics and Science Education, Bandung, Indonesia. https://doi.org/10.2991/icmsed-16.2017.1

Harrison, G. M., \& Vallin, L. M. (2018). Evaluating the metacognitive awareness inventory using empirical factor-structure evidence. Metacognition and Learning, 13(1), 15-38. https://doi.org/ 10.1007/s11409-017-9176-Z

Herlanti, Y., Mardiati, Y., Wahyuningtias, R., Mahardini, E., Iqbal, M., \& Sofyan, A. (2017). Discovering learning strategy to increase metacognitive knowledge in biology learning in secondary school. Jurnal Pendidikan IPA Indonesia [Indonesian Science Education Journal], 6(1), 179-186. https://doi.org/ 10.15294/jpii.v6i1.9605 
Holbrook, J., \& Rannikmae, M. (2009). The meaning of scientific literacy. International Journal of Environmental \& Science Education, 4(3), 275-288.

Huang, C.-H., Wang, T.-F., Tang, F.-I., Chen, I.-J., \& Yu, S. (2017). Development and validation of a quality of life scale for elementary school students. International Journal of Clinical and Health Psychology, 17(2), 180-191. https://doi.org/10.1016/j.ijchp. 2017.01.001

Hwang, J., Choi, K. M., Bae, Y., \& Shin, D. H. (2018). Do teachers' instructional practices moderate equity in mathematical and scientific literacy? An investigation of the PISA 2012 and 2015. International Journal of Science and Mathematics Education, 16(S1), 25-45. https://doi.org/10.1007/ s10763-018-9909-8

Kaiser, H. F. (1970). A second generation little jiffy. Psychometrika, 35(4), 401-415. https://doi.org/ $10.1007 /$ BF02291817

Ke, L., Sadler, T. D., Zangori, L., \& Friedrichsen, P. J. (2021). Developing and using multiple models to promote scientific literacy in the context of socioscientific issues. Science $\mathcal{E}$ Education. https:/ / doi.org/10.1007/s11191-021-00206-1

Khery, Y., Nufida, B. A., Rahayu, S., \& Budiasih, E. (2018). Karakteristik nature of science (NOS) dan penerapan teknologi mobile dalam pembelajaran kimia [Characteristics of Nature of Science (NOS) and Application of Mobile Technology in Chemistry Learning]. Prosiding Seminar Nasional Kimia dan Pembelajarannya 2018 [Proceedings of the 2018 National Chemistry Seminar and Learning], 8897.

Kline, P. (1994). An easy guide to factor analysis. Routledge. https://doi.org/10.4324/9781315788135

Konokman, G. Y., Yelken, T. Y., Karasolak, K., \& Cesur, E. (2017). Teachers' perception: Competent or not in curriculum development. Malaysian Online Journal of Educational Sciences, 5(4), 56-73.

Laugksch, R. C. (2000). Scientific literacy: A conceptual overview. Science Education, 84(1), 71-94. https: / / doi.org/10.1002/(SICI)1098-237X(200001) 84:1<71::AID-SCE6>3.0.CO;2-C

Lelliott, A. (2014). Scientific literacy and the South African school curriculum. African Journal of Research in Mathematics, Science and Technology Education, 18(3), 311-323. https:/ / doi.org/10.1080/ 10288457.2014.967935

Liang, L. L., \& Yuan, H. (2008). Examining the alignment of Chinese national physics curriculum guidelines and 12th-grade exit examinations: A case study. International Journal of Science Education, 30(13), 1823-1835.

https:/ / doi.org/10.1080/09500690701689766
McCoach, D. B., Gable, R. K., \& Madura, J. P. (2013). Instrument development in the affective domain. Springer. https://doi.org/10.1007/978-1-46147135-6

Meyers, L. S., Gamst, G., \& Guarino, A. J. (2017). Applied multivariate research design and interpretation. SAGE. https:/ / us.sagepub.com/en-us/nam/appliedmultivariate-research/book246895

Mun, K., Shin, N., Lee, H., Kim, S.-W., Choi, K., Choi, S.Y., \& Krajcik, J. S. (2015). Korean secondary students' perception of scientific literacy as global citizens: Using global scientific literacy questionnaire. International Journal of Science Education, 37(11), 1739-1766. https://doi.org/ $10.1080 / 09500693.2015 .1045956$

Okada, A. (2013). Scientific literacy in the digital age: Tools, environments, and resources for co-inquiry. European Scientific Journal, 4, 263-274. https://doi.org/10.19044/esj.2013.v9n10p\%25p

Ozdem, Y., Cavas, P., Cavas, B., Cakiroglu, J., \& Ertepinar, H. (2010). An investigation of elementary student's scientific literacy levels. Journal of Baltic Science Education, 9(1), 6-19. http:/ / oaji.net/articles /2014/987-1404740965.pdf

Pahrudin, A., Irwandani, I., Triyana, E., Oktarisa, Y., \& Anwar, C. (2019). The analysis of pre-service physics teachers in scientific literacy: Focus on the competence and knowledge aspects. Jurnal Pendidikan IPA Indonesia [Indonesian Science Education Journal], 8(1), 52-62. https://doi.org/ 10.15294/jpii.v8i1.15728

Rahmasiwi, A., Susilo, H., \& Suwono, H. (2018). Pengaruh pembelajaran diskusi kelas menggunakan isu sosiosains terhadap literasi sains mahasiswa baru pada kemampuan akademik berbeda [The effect of class discussion learning using socioscience issues on new students' scientific literacy on different academic abilities]. Jurnal Pendidikan: Teori, Penelitian, Dan Pengembangan [Journal of Education: Theory, Research and Development], 3(8), 980-989. https://doi.org/ 10.17977/jptpp.v3i8.11373

Ratini, R., Muchtar, H., Suparman, M. A., Tamuri, A. H., \& Susanto, E. (2018). The influence of learning models and learning reliance on students' scientific literacy. Jurnal Pendidikan IPA Indonesia [Indonesian Science Education Journal], 7(4), 458-466. https:/ / doi.org/10.15294/jpii.v7i4.12489

Richards, C. (2012). Policy studies as framework for the renewed role of ethics in science and technology. Philippiniana Sacra, 47(10), 409-442. https:/ / doi.org/10.1111/j.1365-2621.2011.02864.x

Ristanto, R. H., Zubaidah, S., Amin, M., \& Rohman, F. (2017). Scientific literacy of students learned 
through guided inquiry. International Journal of Research \& Review, 4(5), 23-30.

Rohmawati, E., Widodo, W., \& Agustini, R. (2018). Membangun kemampuan literasi sains siswa melalui pembelajaran berkonteks socio-scientific issues berbantuan media weblog [Building students' scientific literacy skills through learning in the context of socio-scientific issues with the help of weblog media]. Jurnal Penelitian Pendidikan IPA [Science Education Research Journal], 3(1), 8-14. https://doi.org/10.26740/jppipa.v3n1.p8-14

Roszkowski, M. J., \& Soven, M. (2010). Shifting gears: Consequences of including two negatively worded items in the middle of a positively worded questionnaire. Assessment $\mathcal{E}$ Evaluation in Higher Education, 35(1), 113-130. https:/ / doi.org/10.1080/ 02602930802618344

Rusilowati, A., Kurniawati, L., \& Nugroho, S. E. (2016). Developing an instrument of scientific literacy assessment on the cycle theme. International Journal of Environmental \& Science Education, 11(12), 57185727.

Rusilowati, A., Nugroho, S. E., Susilowati, E. S. M., Mustika, T., Harfiyani, N., \& Prabowo, H. T. (2018). The development of scientific literacy assessment to measure student's scientific literacy skills in energy theme. Journal of Physics: Conference Series, 983, 012046. https://doi.org/10.1088/1742-6596/983/ $1 / 012046$

Sarkar, M., \& Corrigan, D. (2014). Promotion of scientific literacy: Bangladeshi teachers' perspectives and practices. Research in Science $\mathcal{E}$ Technological Education, 32(2), 162-181. https:/ / doi.org/10.1080/ 02635143.2014.905462

Sartika, D., Kalsum, U., \& Arsyad, A. A. (2018). Analisis kemampuan literasi sains mahasiswa program studi pendidikan fisika Universitas Sulawesi Barat [Analysis of the scientific literacy ability of students of the physics education study program at the University of West Sulawesi]. Jurnal Wahana Pendidikan Fisika [Journal of Physics Education Forum], 3(2), 8-12. https://doi.org/10.17509/ wapfi.v3i2.13722

Schumacker, R. E., \& Lomax, R. G. (2010). A beginner's guide to structural equation modeling. Routledge.

Seraphin, K. D., Philippoff, J., Kaupp, L., \& Vallin, L. M. (2012). Metacognition as means to increase the effectiveness of inquiry-based science education. Science Education International, 23(4), 366-382.

Sharma, O. P. (2015). Ethics in science. Indian Journal of Microbiology, 55(3), 341-344. https://doi.org/ $10.1007 / \mathrm{s} 12088-015-0532-x$

Sharp, J. G., Hopkin, R., \& Lewthwaite, B. (2011). Teacher perceptions of science in the national curriculum: Findings from an application of the science curriculum implementation questionnaire in English primary schools. International Journal of Science Education, 33(17), 2407-2436. https:/ / doi.org/10.1080/09500693.2010.550698

Sofiani, D., \& Mudzakir, A. (2018). Examining junior high school students' views of the nature of science and technology. Proceedings of 155th The IIER International Conference, 12-15.

Subiantoro, A. W., Treagust, D. F., \& Won, M. (2015). Promoting socio-scientific issue-based instruction in Indonesia: Biology teachers experiences and perceptions. Proceedings International Conference on Mathematics, Sciences and Education, 93-104.

Sunarti, T. (2015). Pemahaman literasi sains mahasiswa calon guru fisika Universitas Negeri Surabaya [Understanding of scientific literacy of prospective physics teacher students at the State University of Surabaya]. Proseding Seminar Nasional Fisika dan Pembelajarannya 2015 [Proceedings of the 2015 Physics and Learning National Seminar], 34-39.

Suwono, H., Saefi, M., \& Susilo, H. (2019). Challenge based learning to improve scientific literacy of undergraduate biology students. Proceedings of the 6th International Conference for Science Educators and Teachers 2018, 030020. https://doi.org/10.1063/ 1.5094018

Tabachnick, B. G., \& Fidell, L. S. (2007). Using multivariate statistics. Pearson/Allyn \& Bacon.

Tomás, J. M., Oliver, A., Galiana, L., Sancho, P., \& Lila, M. (2013). Explaining method effects associated with negatively worded items in trait and state global and domain-specific self-esteem scales. Structural Equation Modeling: A Multidisciplinary Journal, 20(2), 299-313. https://doi.org/10.1080/ 10705511.2013.769394

Tytler, R. (2007). Re-imagining science education: Engaging students in science for Australia's future. ACER Press, Australian Council for Educational Research. https:/ / research.acer.edu.au/aer/3

Wei, B., \& Thomas, G. P. (2005). Rationale and approaches for embedding scientific literacy into the new junior secondary school chemistry curriculum in the People's Republic of China. International Journal of Science Education, 27(12), 1477-1493. https:/ / doi.org/10.1080/09500690500154129

Wicaksono, A. G. C., Minarti, I. B., \& Roshayanti, F. (2018). Analysis of students' science motivation and nature of science comprehension in middle school. Jurnal Pendidikan Biologi Indonesia [Indonesian Journal of Biology Education], 4(1), 35. https://doi.org/10.22219/jpbi.v4i1.5354

Ye, F., \& Wallace, T. L. (2014). Psychological sense of school membership scale: Method effects associated with negatively worded items. Journal of 
Psychoeducational Assessment, 32(3), 202-215. Zhang, B., Krajcik, J. S., Sutherland, L. M., Wang, L., Wu, https:/ / doi.org/10.1177/0734282913504816

Yuenyong, C., \& Narjaikaew, P. (2009). Scientific literacy and Thailand science education. International Journal of Environmental and Science Education, 4(3), 335-349.

J., \& Qian, Y. (2005). Opportunities and challenges of China's inquiry-based education reform in middle and high schools: Perspectives of science teachers and teacher educators. International Journal of Science and Mathematics Education, 1(4), 477-503. https:// doi.org/10.1007/s10763-005-1517-8 


\section{APPENDIX A}

\section{Items of Scientific Literacy Questionnaire for Prospective Science Teachers}

\section{Metacognitive $(M)$}

(1) When I complete research procedures, I verify whether the procedures are correct or not

(2) After completing my research projects, I ask myself whether I have reached the goals or not

(3) When doing one procedure, I ask myself whether I have understood all the procedures before continuing to the next procedure

(4) Before doing research, I ask myself whether I have understood the research problems

(5) I search for information and scientific evidence to make a decision

(6) Before doing research, I think of the procedures that will be undertaken

(7) When doing research, I think of the problems for every procedure I complete

\section{The nature and function of science (NFS)}

(1) Science has a significant relationship with human life

(2) Science is affected by civilization and local cultures

(3) Not only technological advancement but also ethics and advantages can be discerned from science

(4) Scientific research should improve human life

(5) How a person uses science and technology will always involve social problem solving

(6) If the scientific problem is very complex and does not have a clear solution, it needs to be reviewed, and the causes of complexity examined

(7) Learning science develops a person's spirituality

\section{Science as human endeavor (SHE)}

(1) Scientists must be honest in conducting and reporting research

(2) Scientists must be open-minded when conducting research

(3) Science, technology, and society are closely interrelated

(4) Public support for scientific research is needed for the development of science

(5) Creativity plays an essential role in the development of scientific knowledge

\section{Habits of mind (HM)}

(1) When doing research, I try to find patterns or sequences in the data

(2) I analyze the data carefully to formulate correct conclusions

(3) When doing research, I look for related information from various sources

(4) I develop or use existing scientific procedures to explain the research

(5) When conducting research, I compare and evaluate information to determine which is most appropriate

\section{Interest in science (IS)}

(1) I consider science as an essential subject to teach

(2) I have a strong motivation to study science

(3) I have a positive attitude toward science as it involves teaching fascinating material

(4) Science helps everyone to have a better life

(5) Science helps me to understand phenomena that occur around me

\section{The teaching of scientific literacy (TSL)}

(1) I always discuss with peers and lecturers when learning science

(2) I do a practicum/experiment/research project in learning science in the class

(3) I use technology to support my learning process

(4) The science learning process that I receive can help me in making decisions 
(5) I am actively involved in the learning evaluation process

\section{A sense of moral and social responsibility (MSR)}

(1) I want to participate in solving problems that affect the lives of people in other parts of the world

(2) I want to play a role in making decisions about scientific issues affecting the world

(3) I try to understand and appreciate people in other parts of the world

Ethics in science (ES)

(1) Research does not need to be carried out systematically

(2) Scientific research does not need to be linked to global impacts

(3) Research we carry out does not need to be linked to other research findings

(4) When doing research, sometimes I skip or omit the research procedures

\section{https://www.ejmste.com}

